Dr. Vildan Donmuș Kaya'

Department of Educational Sciences, Firat University, Elazig, Turkey

Dr. Mehmet Eroğlu

Department of Educational Sciences, Firat University, Elazig, Turkey
Original scientific paper

UDC: 371.39

DOI: $10.5937 /$ IstrPed2002445D

\title{
TURKISH LANGUAGE TEACHER CANDIDATES' PERCEPTIONS OF THE CONCEPT OF DIGITAL STORY: A METAPHOR STUDY ${ }^{2}$
}

\begin{abstract}
The study aims to reveal Turkish Language teacher candidates' metaphorical perceptions of the concept of digital story. The study is phenomenological research, which is one of the qualitative research approaches. The study group consists of 68 Turkish Language teacher candidates studying at Firat University, Education Faculty, Department of Turkish Language Education in 2018-2019. The study uses a purposeful sampling method to determine the study group of the study. To determine the teacher candidates' metaphorical perceptions of the concept of the digital story, the study employs a metaphor questionnaire form developed by the researchers. The metaphors obtained are analyzed according to their reasons, and themes are created. As a result of the research, it is revealed that teacher candidates perceive digital stories as an instructional, mind-building, versatile, facilitating, entertaining, curious, relaxing, remarkable, and transparent tool. These results confirm that digital stories should be used in the training of Turkish Language teacher candidates, and other teacher candidates as well.
\end{abstract}

Keywords: Digital story, metaphorical perceptions, Turkish Language teacher candidates.

\section{Introduction}

Technology is a phenomenon that facilitates human life. Traditional stories, on the other hand, are the approaches that people use to tell about events, situations and share their experiences, which enable them to explain what they want to tell more effectively and interestingly and are used effectively in teaching-learning processes (Gere, Kozolvich \& Kelin, 2002; Lowenthal \& Dunlap, 2010). It would not be wrong to say that these approaches also make people's lives easier and are the technology of the time they are used. These technologies have been transformed into digital platforms since the beginning of the 2oth century and used as digital stories on these platforms. The first studies on digital stories were conducted in 1993 at the digital story center by Joe Lambert and Dana Atchly in their health and community practice studies (Robin, 2008). Aiming to allow people to create their own

\footnotetext{
${ }^{1}$ Corresponding author: vildandnms@gmail.com

${ }^{22}$ This research is improved summary of the presentation of II. International Congress of Innovations and Social Sciences, Elaziğ, Turkey 2019.
} 
stories with small budgets at this center, Lambert pioneered the organization of workshops on digital stories and wrote a book on digital stories (Lambert, 2013). Increasing studies on digital stories have made them necessary to use these stories intensively in the educational environment as well (Demirer, 2013; Diermyer \& Blakesley, 2009;Garrety, 2008; Karakoyun, 2014; Kocaman-Karoglu, 2015). Studies using digital stories as products or tools revealed that digital stories are effective in creating an active classroom environment, supporting language studies, developing creative writing, facilitating the acquisition of social values, and increasing student achievement (Baki, 2019; Balaman, 2016; Kurudayioglu \& Bal, 2014; Yuruk \& Atici, 2017). Also, digital stories help students to think at a higher level and help them read in more depth and meaning (Kurudayioglu \&Bal, 2014).

It is seen in the literature that the concept of the digital story has many definitions. Despite its emphasis on computer technology, digital storytelling is not a new practice. Basically, digital stories typically have narration in the form of recorded audio that provides an emotional element to the story (Robin \& McNail, 2019). Digital stories, in interactive digital platforms that users can control, actively involve the user in the process, enabling them to reinforce this information acquired and apply it to real life, both in a story flow and in this flow, enabling the user to make sense of their information and to construct it in mind. It is an approach that can last from 3 minutes to 5 minutes (Dush, 2009; Garrety, 2008; Menezes, 2012; Tunc \& Karadag, 2013). Digital stories are products created in teaching and learning processes in many different fields such as mathematics, science, fine arts, social studies, and values education in some studies (Balaman, 2015; Balaman, 2016; Demir \& Kilickiran, 2018; Gomleksiz \& Pullu, 2017; Kabaran, Karalar, Altan \& Altintas, 2019; Kotluk \& Kocakaya, 2015; Kutlucan, Cakir \& Unal, 2019; Tatli \& Aksoy, 2017; Tatli \& Bayramoglu, 2015; Uslupehlivan \& Kurtoglu Erden, 2017). It is seen that digital stories are used as teaching material in some studies (Polater, 2019; Tabak, 2017; Yuruk \& Atici, 2017). Some of the studies related to the digital story are review and content analysis studies (Inceelli, 2005; Kocaman Karoglu, 2015; Kungeru, 2016; Tunc \& Karadag, 2013; Yilmaz, Ustundag \& Gunes, 2017; Yuzer \& Kilinc, 2015) Digital stories are used in Turkish lesson teaching as well as in many lessons (Cigerci \& Gultekin, 2017; Kurudayioglu \& Bal, 2014). Studies on the use of digital stories in Turkish teaching are mostly related to reading and writing skills (Baki \& Feyzioglu, 2017a; Baki \& Feyzioglu, 2017b; Dayan, 2017; Ertan Ozen, 2017; Gunduz, 2019; Sarica \& Usluel, 2016; Tabak, 2017).

Digital stories that are used effectively in many fields are important and effective teaching material for both teacher and student (Robin, 2006). Because, Digital Stories can be a powerful educational tool for students at all ages and grade levels who are tasked with creating their own stories (Robin, 2016). Digital stories also enable teacher candidates to acquire 21st-century skills (Robin, 2008; Niemi \& Multisilta, 2016). This is very important for teacher candidates who will become teachers of the 21st century. On one hand, teachers candidates are likely to encounter digital stories, which are important and effective teaching materials, in their career, on the other hand, when the relevant literature is analyzed, it is determined that the digital story studies about Turkish Language teacher candidates are scanty and insufficient. For this reason, the opinions of the Turkish Language teacher candidates who will become 21st-century teachers should be revealed.

When the literature is examined, it is seen that metaphors are frequently used to investigate the perceptions of individuals and some of these studies are aimed at determining the perceptions of teacher candidates (Akyol \& Kiziltan, 2019; Beyoglu \& Ergin, 2019; Cavusoglu \& Tepebasili, 2019; Celik \& Incili, 2019; Eker \& Sicak, 2019; Demirer \& Baki, 2018; Gezgin, 
Hamutoglu, Sezen Gultekin \& Yildirim, 2019; Gurol \& Donmus, 2010; Sola Ozguc, Uzunkol \& Uysal, 2019; Toksun, 2019; Yapicioglu \& Korkmaz, 2019). Metaphors "allow the individual to express a concept or phenomenon in the way he perceives it by using metaphors" (Aydin \& Pehlivan, 2010). In this context, metaphors can be considered as important data collection tools, especially for social sciences (Yildirim \& Simsek, 2011). It is thought that the results of this research will provide important conclusions regarding Turkish Language teachers' perceptions of digital stories. Also, due to the small number of metaphors related to the concept of digital stories in the literature, this study will contribute to overcoming this shortcoming in the literature. Besides, since the metaphor studies related to the concept of digital stories in the literature are insufficient, this study will contribute to overcoming this shortcoming in the literature.

The study also aims to reveal the metaphorical perceptions of Turkish teacher candidates regarding the concept of the digital story. In this context, answers to the following questions are sought:

1. What are the metaphors of Turkish Language teacher candidates regarding the concept of the digital story?

2. In which themes do Turkish Language teacher candidates' metaphors regarding the concept of the digital story take place in terms of their reasons?

\section{Method}

\subsection{Research Design}

This study is designed in a qualitative research approach and the "phenomenology" method is used to reveal Turkish language teachers' views about professional development barriers. The phenomenology research aims to investigate phenomena that we are not entirely unfamiliar with but which we cannot fully understand (Yildirim \& Simsek, 2013). The purpose of phenomenological research is to describe the different ways in which people experience a particular direction of a phenomenon, interpretation, meaning, or conceptualization (Cepni, 2007). Phenomenological research deals with what people perceive, understand, and experience about the phenomena they encounter in the universe they live in(Patton, 2002; Cekmez, Yildiz \& Butuner, 2015). So, a phenomenological approach is well suited to studying effective, emotional, and often intense human experiences (Merriam, 2009).

\subsection{Participants}

The criterion sampling method, one of the purposeful sampling methods, was used in the selection of the participants of the research. Because in "Phenomenology" researches, data sources should be individuals or groups that experience the phenomenon that the research focuses on and that can express this phenomenon (Yildirim \& Simsek, 2011). At the same time, these groups must have experienced the phenomenon in all its aspects (Creswell, 2013). The teacher candidates participating in the study must have experienced the digital story phenomenon. For these reasons, the experience of the "digital story" phenomenon was chosen as a criterion in the selection of the teacher candidates participating in the study. Teacher candidates can experience the phenomenon of the digital story in the Instructional Technology and Material Design course. Therefore, the study group consists of 68 Turkish Language teacher candidates who experience the phenomenon of the digital story in the Instructional Technology and Material Design course studying at Firat University, Education 
Faculty, Department of Turkish Education in 2018-2019. 78\% $(n=53)$ of the teacher candidates participating in the study are female and $22 \%(n=15)$ are male.

\subsection{Data Collection Tool}

Metaphors were used to collect data in the research. Metaphors move facts from one area to another, filter the truth, and define it simply. Metaphors frequently used in social sciences allow describing the situation, events, or facts as they exist (Yildirim \& Simsek, 2011). It is aimed to determine the perceptions of pre-service teachers about the digital story concept using metaphors in this study. The research data was collected through the metaphor questionnaire form. The questionnaire form consists of three sections. In the first section, personal information is included to determine the demographic characteristics of teacher candidates. In the second section, the definition of the digital story in the literature and used in the course is given in order not to cause any confusion. In the last part of the form, "Digital story ........... is as / similar; because ..........." "There is an open-ended question in the form.

\subsection{Data Collection and Analysis}

The research data were collected by the researchers after the digital story creation process of the Instructional Technologies and Material Design course was completed because, in phenomenology researches, the participants must have experienced the phenomenon, event, or concept that is the subject of the research (Yildirim \& Simsek, 2011). After the questionnaire forms were given to teacher candidates, it was mentioned to the teacher candidates that the structure of the metaphor, which constitutes the essence of the study, consists of three elements and that these elements are goals, sources, and associations (Aygun, Hacioglu \& Durukan, 2014). To set an example and better understand, a metaphor example is given about the concepts of the social network, school, and teacher.

Metaphor questionnaire forms collected from teacher candidates were transferred to the Excel program by the researchers. The data was then analyzed in four steps according to the metaphor analysis method proposed by Saban (2008). The metaphor analysis method steps used in the study are as follows:

1. Coding and extraction phase: At this stage, teacher candidates' metaphors about the concept of the digital story are listed alphabetically. After the listed process, the data of two of the preservice teachers who left the metaphor reason empty or did not provide a logical justification were not evaluated. The metaphors developed by the participants are simply coded. Codes of teacher candidates who developed metaphors and metaphors were entered into the Excel program as data. To determine which teacher candidate was developed by metaphor, the coding method was used. Teacher candidates identified by sequence numbers as $T_{1}, T_{2}, T_{3} \ldots$ to determine which teacher candidate was developed by metaphor. By analyzing this created Excel file list, it has been determined which metaphor density is shown. After the listing, the study was conducted with 66 valid metaphors.

2. Example metaphor image compilation phase: At this phase, metaphors entered in the Excel program are listed alphabetically. A sample metaphor image, which is thought to represent it best, was developed from the same metaphors by examining the metaphors. 
3. Category development phase and adding it as data entry: 66 metaphors obtained by examining metaphors developed by teacher candidates are divided into seven different themes in terms of similar features. It was also themed according to 66 metaphor reasons, and as a total of nine different themes, it was written as data entry on the line with related metaphors in Excel. These themes are presented in the tables and direct quotations about metaphors that are stronger in expressing themes are given below the tables.

4. Validity and reliability: In the study, the metaphors were examined by a different researcher who had previously studied metaphors apart from the researchers according to the codes created according to the subject-source association and the suitability of the main metaphors. To demonstrate consensus among researchers and another researcher, the percentage of agreement was determined as 93\% using Miles and Huberman's (1994) percentage adaptation formula (Percentage of agreement $=$ [Consensus / Disagreement + Consensus] * 100). After the review, the data were rearranged by reaching a consensus on the metaphors that the researchers and the other controlling researchers disagreed with. There are two important factors to ensure the validity of the results in the study (Yildirim \& Simsek, 2011). The first is credibility. To ensure credibility, research data found to be incomplete or inaccurate were removed. In reporting the results of the research, the direct quotations were given by keeping the identity information of the participants confidential, and the encodings ( $\mathrm{T} 1, \mathrm{~T} 2, \mathrm{~T} 3 \ldots$ etc) determined for each teacher candidate was presented at the beginning of the direct quotations. The second factor is transferability. For the transferability of the research, metaphors are described in detail; however, the data collection and analysis process are given in detail.

\section{Findings}

In this part of the study, the metaphors developed by teacher candidates for the concept of the digital story are explained by presenting them in tables showing frequencies according to their main metaphors and then according to their themes. The frequency values in these tables are calculated according to the total number of valid metaphors and rationales developed by the teacher candidates.

\section{Findings Related to Metaphors Developed by Turkish Teacher Candidates Regarding the Concept of Digital Story}

The metaphors of Turkish Language teacher candidates regarding the concept of a digital story and the main metaphors formed by grouping these metaphors are given in Table 1.

Table 1. Main metaphors about the concept of the digital story

\begin{tabular}{|c|c|c|c|c|c|c|}
\hline Metaphor & $f$ & $\begin{array}{ll}\text { Main } & f \\
\text { metaphor }\end{array}$ & Metaphor & $f$ & $\begin{array}{l}\text { Main } \\
\text { metaphor }\end{array}$ & $f$ \\
\hline \multirow[t]{2}{*}{ Accessory } & 1 & \multirow{8}{*}{ ס } & Garden & 1 & \multirow{8}{*}{ 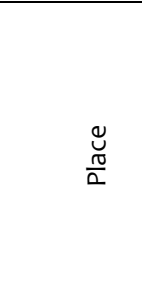 } & \multirow[t]{8}{*}{9} \\
\hline & 1 & & & 1 & & \\
\hline Encyclopedia & & & Top of the & & & \\
\hline Computer game & 1 & & Sea & 1 & & \\
\hline Cartoon & 3 & & House & 1 & & \\
\hline Lighthouse & 1 & & Sky & 1 & & \\
\hline Movie & 1 & & Library & 1 & & \\
\hline Photo & 1 & & Lunapark & 1 & & \\
\hline
\end{tabular}




\begin{tabular}{|c|c|c|c|c|c|c|}
\hline Trailer & 1 & \multirow{19}{*}{37} & School & 1 & & \\
\hline eyeglasses & 2 & & Ocean & 1 & & \\
\hline External memory & 1 & & Car & 4 & \multirow{4}{*}{$\frac{\frac{d}{U}}{\frac{U}{d}}$} & 7 \\
\hline Book & 5 & & High-speed train & 1 & & \\
\hline Crutch & 1 & & Bus & 1 & & \\
\hline Bridge & 2 & & Railway car & 1 & & \\
\hline Lamp & 1 & & Mother & 1 & \multirow{3}{*}{ 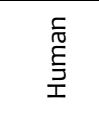 } & \multirow[t]{3}{*}{5} \\
\hline Story & 2 & & Child & 1 & & \\
\hline Storybook & 2 & & Teacher & 3 & & \\
\hline Food processor & 1 & & Chocolate & 1 & \multirow[t]{2}{*}{ Food } & \multirow[t]{2}{*}{2} \\
\hline Olympic Races & 1 & & Pomegranate & 1 & & \\
\hline Game & 2 & & Chameleon & 1 & Animal & 1 \\
\hline Window & 1 & & Photosynthesis & 1 & \multirow{7}{*}{$\frac{\grave{\Phi}}{\frac{1}{+}}$} & 5 \\
\hline Puzzle & 1 & & Light & 1 & & \\
\hline Advertisement & 1 & & Blackhole & 1 & & \\
\hline Chess & 1 & & Seasons & 1 & & \\
\hline Poem & 1 & & Autumn & 1 & & \\
\hline Theater play & 1 & & & & & \\
\hline brainbox & 1 & & & & & \\
\hline
\end{tabular}

As can be seen in Table 1, when the metaphors developed by teacher candidates regarding the concept of digital story are examined, the main metaphor themes created are tools $(f=37)$, place $(f=9)$, vehicle $(f=7)$, human $(f=5)$, food $(f=2)$ and animal $(f=1)$. The last main metaphor theme is determined as the other $(f=5)$ with metaphors that cannot be included in the determined main metaphor themes. It was determined that the most developed metaphors were in the main metaphors of tools, places, and vehicles. When the developed metaphors are analyzed in general, it is seen that the most repeating metaphors are books ( $f$ $=5)$, cars $(f=4)$, cartoons $(f=3)$, and teachers $(f=3)$.

\section{Findings Related to the Reasons of the Metaphors Developed by Turkish Teacher Candidates Regarding the Concept of Digital Story}

The metaphors obtained from Turkish Language teacher candidates were divided into themes by the researchers according to their reasons, and the reasons for pre-service teachers to determine these metaphors were discussed. The expression "because ........" in the metaphor questionnaire form has been determined as a criterion for including the reasons in the themes. Some metaphors are in more than one theme according to their reasons. For example, the "car" metaphor has been included in the themes of a versatile vehicle, a facilitating vehicle, and a relaxing vehicle. One of the rationales is "... Because it performs more than one task at the same time", while the other is expressed as "... .. because it speeds up and facilitates teaching."

Table 2. Metaphor rationale themes developed for the concept of the digital story

\begin{tabular}{ll}
\hline Theme & $\mathbf{f}$ \\
\hline A versatile tool & 12 \\
A remarkable tool & 3 \\
An entertaining tool & 4 \\
\hline
\end{tabular}




\begin{tabular}{ll}
\hline A facilitating tool & 4 \\
An intriguing tool & 5 \\
An instructional tool & 21 \\
A relaxing tool & 2 \\
A transparent tool & 1 \\
A mind-building tool & 15 \\
\hline Total & 66 \\
\hline
\end{tabular}

As seen in Table 2, the reasons for the digital story concept metaphors are divided into nine themes after the coding and extraction step. The themes created by metaphors are as follows: (1) A versatile tool, (2) A remarkable tool, (3) An entertaining tool, (4) A facilitating tool, (5) An intriguing tool, (6) An instructional tool (7) A relaxing tool, (8) A transparent tool, and (9) A mind-building tool. The themes created as a result of the analysis of the metaphors developed by teacher candidates regarding the concept of the digital story are explained below in detail.

A versatile tool (Theme 1): A versatile tool is one of the themes $(f=12)$ highlighted by the teacher candidates related to the digital story. Metaphors and quotations regarding this theme are given in Table 3.

Table 3. Metaphors and quotations about the concept of digital story as a versatile tool

\begin{tabular}{|c|c|c|c|}
\hline & $f$ & Metaphors & Quotations \\
\hline 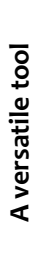 & 12 & $\begin{array}{l}\text { Encyclopedia, Car, } \\
\text { Garden, Chameleon, } \\
\text { House, Photograph, } \\
\text { Photosynthesis, } \\
\text { External Memory, } \\
\text { Pomegranate, } \\
\text { School, Ocean, } \\
\text { Poetry }\end{array}$ & $\begin{array}{l}\text { T59: is like an encyclopedia because it contains a lot of } \\
\text { information. } \\
\text { T37: is like a home because it contains many different things. } \\
\text { T31: is like an external memory because it contains information, } \\
\text { pictures, sounds. } \\
\text { T22: is like a school because a lot of different elements have come } \\
\text { together for the learning environment. } \\
\text { T30: is like the ocean because it contains a lot of information on it. }\end{array}$ \\
\hline
\end{tabular}

Under this theme, teacher candidates emphasized that digital story is a versatile tool and used 12 different metaphors for this. Metaphors such as the encyclopedia, home, garden used here strikingly emphasize that digital stories are a versatile tool for teacher candidates.

A remarkable tool (Theme 2): One of the highlighted themes related to the digital story is the theme of digital stories being a remarkable tool. Under this theme, teacher candidates used three different metaphors to emphasize that a digital story is a remarkable tool. Metaphors and quotations regarding this theme are given in Table 4.

Table 4. Metaphors and quotations about the concept of digital story as a remarkable tool

\begin{tabular}{|c|c|c|c|}
\hline & $f$ & Metaphors & Quotations \\
\hline 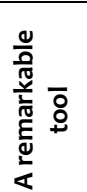 & 3 & $\begin{array}{l}\text { Cartoon, Child, } \\
\text { Movie. }\end{array}$ & $\begin{array}{l}\text { T32: is like a cartoon because it catches the student's attention. } \\
\text { T64: is like a child because it is interesting and interesting. } \\
\text { T39: is like a movie, because you get your attention and watch it. }\end{array}$ \\
\hline
\end{tabular}


An entertaining tool (Theme 3): One of the themes mentioned about the digital story is an entertaining tool theme. Under this theme, teacher candidates used four different metaphors to emphasize that a digital story is an entertaining tool. Metaphors and quotations regarding this theme are given in Table 5.

Table 5. Metaphors and quotations about the concept of digital story as an entertaining tool

\begin{tabular}{llll}
\hline & $\mathbf{f}$ & Metaphors & Quotations \\
\hline 4 & Cartoon, & T51: is like a cartoon because it provides teaching in fun ways. \\
Game, Chess, & T20: is like a game because it is both instructive and entertaining. \\
Amusement & T26: is like chess because it both entertains and teaches. \\
& & Park. & T24: is like an amusement park because it teaches while \\
& & entertaining.
\end{tabular}

A facilitating tool (Theme 4): Another highlighted theme related to the digital story is a facilitating tool theme. Under this theme, teacher candidates used three different metaphors to emphasize that a digital story is a facilitating tool. The car metaphor is highlighted more than once. Metaphors and quotations regarding this theme are given in Table 6.

Table 6. Metaphors and quotations about the concept of digital story as a facilitating tool

\begin{tabular}{llll}
\hline & $\mathbf{f}$ & Metaphors & Quotations \\
\hline & 4 & Car, High- & T35: is like a car because it speeds up and makes teaching easier. \\
& speed & T43: is like a car because it allows us to learn fast. \\
train, Food & T9: is like a high-speed train because its instructive aspect is quick and \\
processor. & $\begin{array}{l}\text { easy. } \\
\text { T27: is like a food processor because it makes the job easier for the } \\
\text { teacher. }\end{array}$
\end{tabular}

An intriguing tool (Theme 5): One of the highlighted themes related to digital stories is an intriguing tool theme. Under this theme, teacher candidates used five different metaphors to emphasize that a digital story is a curious tool. Metaphors and quotations regarding this theme are given in Table 7.

Table 7. Metaphors and quotations about the concept of digital story as a curious tool

\begin{tabular}{lll}
\hline $\mathbf{f}$ & Metaphors & Quotations \\
\hline 5 & $\begin{array}{l}\text { Computer } \\
\text { Game, Top of } \\
\text { the Mountain, }\end{array}$ & $\begin{array}{l}\text { T65: is like a computer game, because the end is eagerly awaited. } \\
\text { T28 like top of the mountain, because its end is unpredictable, }\end{array}$ \\
& $\begin{array}{l}\text { Trailer, Story, } \\
\text { Olympic }\end{array}$ & $\begin{array}{l}\text { T18: is like a story because it educates and teaches unconsciously } \\
\text { while entertaining and arousing curiosity. }\end{array}$ \\
& Races & T8: is like an Olympic race, because it motivates and motivates \\
people to succeed.
\end{tabular}

An instructional tool (Theme 6): One of the themes most frequently emphasized by teacher candidates regarding the digital story $(f=21)$ is an instructional tool theme. Metaphors and quotations regarding this theme are given in Table 8. 
Table 8. Metaphors and quotations about the concept of digital story as a teaching tool

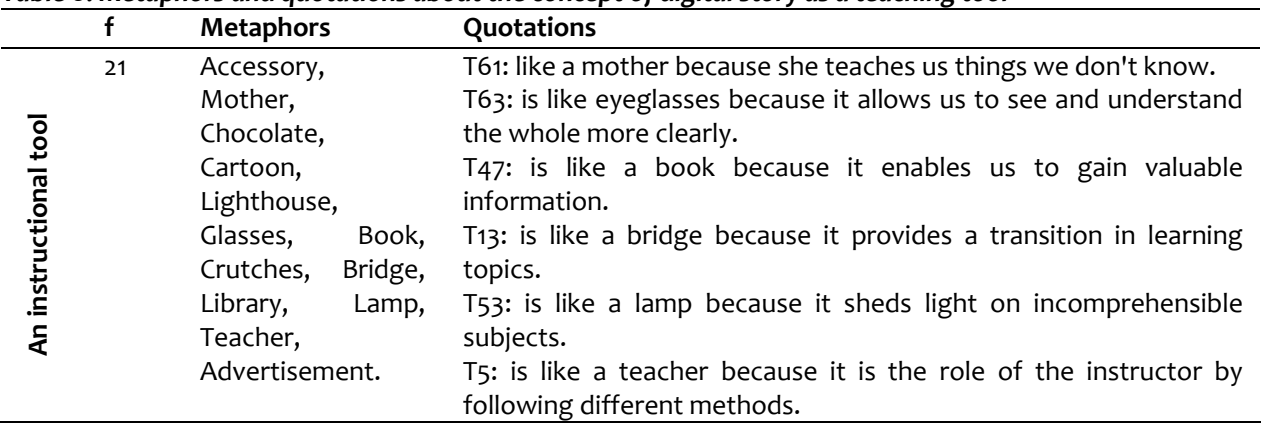

Under this theme, teacher candidates emphasized that digital story is a teaching tool and used 13 different metaphors for this. Book, bridge, glasses, and teacher metaphors were used more than once. Metaphors such as mother, book, teacher used here strikingly emphasize that digital stories are an instructional tool for teacher candidates.

A relaxing tool (Theme 7): Another theme emphasized by teacher candidates regarding the digital story is a relaxing tool theme. Under this theme, teacher candidates used two different metaphors to emphasize that a digital story is a relaxing tool. Metaphors and quotations regarding this theme are given in Table 9.

Table 9. Metaphors and quotations about the concept of digital story as a relaxing tool

\begin{tabular}{|c|c|c|c|}
\hline & $f$ & Metaphors & Quotations \\
\hline 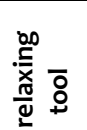 & 2 & Sea, car. & $\begin{array}{l}\text { T1: is like the sea because you do not get bored as you watch it, you will } \\
\text { feel comfortable. } \\
\text { T11: is like a car because it provides comfort in the learning process. }\end{array}$ \\
\hline
\end{tabular}

A transparent tool (Theme 8): The least emphasized $(f=1)$ theme of teacher candidates regarding the digital story is a transparent tool theme. Under this theme, pre-service teacher candidates used a metaphor to emphasize that a digital story is a transparent tool. Metaphors and quotations regarding this theme are given in Table 10.

Table 10. Metaphors and quotations about the concept of digital story as a transparent tool

\begin{tabular}{llll} 
& $\mathbf{f}$ & Metaphors & Quotations \\
\hline & 1 & Seasons & T3: It is like the seasons because it is displayed completely if it \\
is positive or negative.
\end{tabular}

A mind-building tool (Theme 9): A mind-building tool is one of the themes ( $f=14$ ) emphasized by teacher candidates regarding the digital story. Metaphors and quotations regarding this theme are given in Table 11. 
Table 11. Metaphors and quotations about the concept of digital story as a mind-building tool

\begin{tabular}{|c|c|c|c|}
\hline & $f$ & Metaphors & Quotations \\
\hline 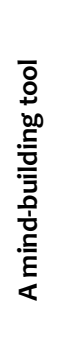 & 15 & $\begin{array}{l}\text { Trailer, Sky, } \\
\text { Light, Black } \\
\text { Hole, Story, } \\
\text { Storybook, Bus, } \\
\text { Game, Window, } \\
\text { Puzzle, } \\
\text { Autumn, } \\
\text { Theater Play, } \\
\text { Wagon, } \\
\text { Brainbox. }\end{array}$ & $\begin{array}{l}\text { T50: is like a trailer because it does not give you what it wants to } \\
\text { teach directly, you complete it. } \\
\text { T6: is like light because it provides enlightenment of our minds. } \\
\text { T33: is like a black hole, because it takes place in the mind in a short } \\
\text { way and affects the mind. } \\
\text { T23: is like a storybook, because what you want to be told is explained } \\
\text { by examples by developing our imagination without boring. } \\
\text { T10: is like autumn because there is a message in it. You should } \\
\text { understand it. } \\
\text { T6: is like a theater play because there is a message it wants to give. }\end{array}$ \\
\hline
\end{tabular}

Under this theme, pre-service teachers emphasized that digital story is a mind-building tool and used 12 different metaphors for this. The fairy tale book metaphor, one of these metaphors, was used more than once. Metaphors such as the puzzle and the brainbox used here strikingly emphasize that digital stories structure the mind for teacher candidates.

\section{Discussion, Conclusion, and Suggestions}

Digital stories are known as the modern reflection of storytelling, which is an effective teaching method in learning-teaching environments that transform and evolve with technology (Robin, 2008). It is seen that most of the studies in the literature using digital stories have resulted positively. In the studies on digital stories, it was concluded that digital stories have positive effects on many variables such as students' achievement, reading/writing skills motivations and attitudes towards the course (Uslupehlivan \& Kurtoglu Erden, 2018; Yuruk, 2015). In this context, Turkish Language teacher candidates who were presented with digital story examples related to their fields in Instructional Technologies and Material Design courses were asked to developed metaphors to reveal their perceptions regarding this phenomenon.

Findings of the research revealed that Turkish Language teacher candidates perceive digital stories more as tools and materials and liken them to books and cartoons the most. In the study conducted by Yuruk and Atici (2017), it was determined that the materials in the form of cartoons draw more attention and be more effective. Also, it was determined that the students liked the digital stories that they likened to cartoon movies at a high rate. It was seen that teacher candidates emphasized the concept of the teacher regarding the instructional aspect of digital stories, and the concept of the car regarding the speed of instructional aspect in the study. It can be said that digital stories are generally perceived as instructive, mind-building, intriguing, facilitating, entertaining, remarkable, relaxing, and transparent tool.

It is known that Robin (2008) groups digital stories into three different types, one of which is digital stories used in education in informative or instructional stories. Also, Kilic (2014) mentioned that digital stories can be used to raise awareness about the subject, reduce cognitive load, and support learning while drawing attention to the teaching aspect. Wang and Zhan (2010) state that digital stories affect and support learning. In some studies, it has been emphasized that digital stories are an instructional tool and it is stated as "an effective teaching tool for teachers" or "an effective learning tool for students" (Clarke \& Adam, 2012; Nilsson, 2008; Robin, 2006). Also, Robin (2008) stated that teachers have the option of showing previously-created digital stories to their students to introduce content and capture 
students' attention when presenting new ideas. The finding that turkish language teacher candidates' perceptions regarding digital stories as an instructional tool in the study also obtained in other studies. Therefore, digital stories can be considered as effective learning and teaching tools. As a matter of fact, the idea that digital stories will be an effective tool in the teaching-learning process is an important reason for its use in education.

Digital stories are the tools that allow the user to apply the story in real life by giving the control, reinforce it with the repetition of the story, and provide the ability to think according to himself by reviving the subject in his mind (Inceelli, 2005). In other words, digital stories enable the student to get to know himself and to use his imagination effectively. (Miller \& Pennycuff, 2008; Tompkins, 2004). In this context, Woodhouse (2008) stated that one of the advantages of digital stories is that it enhances creativity, imagination, and concentration. In another study, it is stated that digital stories draw attention in terms of developing people's creative thinking skills and imagination (Duveskog, Tedre, Sedano \& Sutinen, 2012). The ability of digital stories highlighted in the relevant literature to develop creativity and structure the mind can be associated with pre-service teachers' perception of digital stories as a mindbuilding tool. It is noteworthy that digital stories, which are justified as a mind-building tool, are expressed using metaphors such as puzzles and brainboxes. Therefore, this approach is considered to be a different, creative, and functional approach for the new generation that will shape the future in the field of education (Bozdogan, 2012).

Digital stories are multi-dimensional learning-teaching tools with different approaches and applications offered by the technology of the age (Baki, 2019). Turkish language teacher candidates emphasized the presence of diverse elements and diversity of information in digital stories in the theme of digital stories being a versatile tool. As Robin (2006) stated, digital stories are the combination of digital materials such as audio, video, pictures, etc. to present information on a subject. In other words, he pointed out that digital stories consist of too many items. It can be seen as one of the benefits of the versatility that digital stories provide benefits to the individual in terms of combining, integrating, and analyzing visual and audio elements with a written text (Robin, 2008). Ohler (2008) expressed digital stories as creating a personal video by using many media tools and harmoniously combining them. The definitions made in the literature and the expressions of teacher candidates confirm that digital stories are formed by the combination of many items. The expressions of teacher candidates show that the versatility of digital stories is related to the fact that digital stories contain different skills. In this context, LaFrance and Blizzard (2011) stated that digital stories provide students with communication skills, research skills, and the ability to work collaboratively. Also, Hathorn (2005) points out that digital stories are tools to develop literacy, language, and communication skills by using technological opportunities.

The fact that digital stories are perceived by Turkish language teacher candidates as an intriguing and facilitating tool is another finding of the study. These themes emphasize that teacher candidates' perceptions of digital stories as a facilitating tool in terms of accelerating learning. Therefore, digital stories can be defined as tools used in teaching-learning environments, stimulating students' curiosity, increasing their learning speed, and naturally facilitating learning. The more stimulants are included in the learning environment for learners, the more motivational drives are motivated. Tunc and Karadag (2013) stated that with a digital story, the learner entered a different educational environment and perhaps encountered a learning environment that he was not accustomed to before. It is an undeniable fact that the curiosity of the learner increases with the tool encountered in a 
different and unfamiliar learning environment. Robin (2008) emphasized that the visual images combined with written texts provide the development and acceleration of students' understanding levels by expressing the facilitating feature of digital stories in increasing the speed of learning. Balaman (2016) stated that learning with digital stories can happen in a shorter time. Yuruk (2015) stated that not only learning but also the teacher will be shortened by using digital stories and stated that the transfer time of the instructional message will be shortened by removing the technological obstacles and providing suitable conditions.

The teacher candidates emphasized that digital stories make teaching more entertaining. In general, stories are an attractive and binding method of education with their spiritual, historical, psychological, philosophical, and sociological meanings. Stories entertain, excite, cheer, explain, and teach (Yuruk \& Atici, 2017). It is also possible to say these for digital stories, which are the digital form of stories. In this context, Baki and Feyzioglu (2017b: 689) stated that "the dynamic and powerful tool (digital stories) that covers many of today's generation's expectations has various advantages that will enable the student to enjoy knowledge with an understanding parallel to the constructivist approach's" learning by living "perspective. Moreover, the students who participated in the study of Yilmaz, Ustundag, Gunes, and Caliskan (2017) stated that the course will be fun with all the readings in the textbooks as digital stories.

Torres, Ponca, and Pastor (2012) emphasize that digital stories increase students' level of interest and attention and that they are an educational tool for teachers. This explains why teacher candidates who participated in the study perceived digital stories as a remarkable tool. There are also different studies stating that digital stories attract the attention of learners with visual materials, arouse their interest, and increase their motivation (Robin, 2006; Yuruk \& Atici, 2017).

Another finding of digital stories in the study is that digital stories are emphasized as a relaxing and transparent tool by Turkish language teacher candidates. Teacher candidates stated that digital stories are not boring, they are also a relaxing tool and provide comfort in learning. It is possible to see similar findings in other studies. Tsou, Wang, and Tzeng (2006) stated that digital stories distract the feeling of boredom by keeping students' attention on the subject. Moreover, Turkish language teacher candidates stated that, as a transparent tool, digital stories show everything as they are, such as seasons. There are similar findings in the literature related to this finding. One of them is the finding obtained in the study conducted by Yuruk and Atici (2017). In this study, although few students state that they do not understand the stories, it is seen that most of the students do not have problems in understanding digital stories.

This study aims to reveal the metaphorical perceptions of Turkish Language teacher candidates regarding the concept of the digital story. Findings of both the other studies and the current study show that the perception of teacher candidates regarding digital stories is positive. In this context, it is thought that digital stories should be used as a teaching tool in the process of teaching both teacher candidates and students at other educational levels. Besides, it is thought that digital stories can be used to make teaching environments entertaining, attractive, and intriguing. Moreover, it can be said that digital stories can be used to make the teaching environment transparent, relaxing, and facilitating learning. 


\section{Limitations and Suggestions}

The results obtained in the study are limited to the sample of the study. Besides, the perceptions of Turkish language teacher candidates regarding the single concept were examined in the research. This can be considered a limitation. But, Creswell (2013) stated that only a concept should be examined in "phenomenology studies". Quantitative, qualitative, and mixed research can be done to reveal the effects of digital stories in the teaching process of pre-service education. In particular, experimental or mixed-method researches that will reveal the effect of digital stories on the development of language skills of Turkish Language teachers should be conducte.

\section{References}

Akyol, C. \& Kiziltan, O. (2019). Ogretmen adaylarinin kultur kavramina iliskin metaforlari. Gazi Universitesi Gazi Egitim Fakultesi Dergisi, 39(2), 937-961. ISSN-1301-9058.

Aydin, I. S. \& Pehlivan, A. (2010). Turkce Ogretmeni adaylarinin "Ogretmen" ve "Ogrenci" kavramlarina iliskin kullandiklari metaforlar. Turkish Studies, 5(3), 818842.http://dx.doi.org/10.7827/TurkishStudies.1574.

Aygun, M., Hacioglu, Y. \& Durukan, U.G. (2014). Prospective science teachers' metaphorical images about 'Light', International Conference on Education and Social Sciences, Proceedings of INTCESS14, Istanbul, 1380-1388.

Baki, Y. \& Feyzioglu, N. (2017a). Dijital Oykulerin 6. Sinif Ogrencilerinin yazmaya yOnelik tutumlarina etkisi. Mustafa Kemal Universitesi Sosyal Bilimler Enstitusu Dergisi, 14(40), 3158.

Baki, Y. \& Feyzioglu, N. (2017b). Dijital Oykulerin 6. Sinif Ogrencilerinin Oyku yazma becerilerine etkisi. International Online Journal of Educational Sciences, 9(3). https://doi.org/10.15345/iojes.2017.03.009

Baki, Y. (2019). Turkce Ogretmeni adaylarinin yaratici yazma becerilerinin gelistirilmesinde dijital Oykulerin etkisi. Ana Dili Egitimi Dergisi, 7(4), 964-995. https://doi.org/10.16916/aded.597269

Balaman, F. (2015). Dijital Oykuleme yOnteminin Ogrencilerin toplumsal deger yargilarina etkisi. Elektronik Egitim Bilimleri Dergisi, 4 (8), 159-168.

Balaman, F. (2016). Dijital Oykulemenin universite Ogrencilerinin demokratik deger yargilarina etkisi: Mustafa Kemal Universitesi Ornegi. Current Research Education, 2(1), 42-52.

Beyoglu, A. \& Ergin, D. Y. (2019). Ogretmen adaylarinin siddet kavramina iliskin algilarinin metafor analizi yoluyla incelenmesi. Trakya Universitesi Sosyal Bilimler Dergisi, 21(1), 283294. https://doi.org/10.26468/trakyasobed.486994

Bozdogan, D. (2012). Content analysis of ELT students' digital stories for young learners. Novitas-ROYAL (Research on Youth and Language), 6 (2), 126-136.

Cavusoglu, A. A. \& Tepebasili, F. (2019). The metaphors that candidate teachers used for a foreign language teacher. IBAD Sosyal Bilimler Dergisi, (Ozel Sayi), 12-24. DOI: 10.21733 /ibad.606554

Celik, T. \& Incili, O. F. (2019). Sosyal bilgiler Ogretmen adaylarinin algilarinda nufus ve harita bilgisi konusu: bir metafor calismasi. Muallim Rifat Egitim Fakultesi Dergisi, 1(1), 22-41.

Cigerci, F. M. \& Gultekin, M. (2017). Use of digital stories to develop listening comprehension skills. Issues in Educational Research, 27(2), 252. 
Clarke, R. \& Adam, A. (2012). Digital storytelling in Australia: Academic perspectives and reflections. Arts and Humanities in Higher Education, 11(1-2), 157-176. https://doi.org/10.1177/1474022210374223

Creswell, J. W. (2013). Nitel arastirma yOntemleri: Bes yaklasima gOre nitel arastirma ve arastirma deseni (Ucuncu baskidan cev.) (M. Butun ve S. B. Demir). Siyasal Kitabevi, Ankara.

Dayan, G. (2017). Ilkokul Ogrencilerinin Turkce dersinde dijital Oykuleme calismalari. [Unpublished master's thesis]. Eskisehir Osmangazi Universitesi, Egitim Bilimleri Enstitusu.

Demir, S. \& Kilickiran, H. (2018). Dijital oyku uygulamasinin ozel yetenekli ogrencilerin yazma becerilerine etkisi. Disiplinlerarasi Egitim Arastirmalari Dergisi, 2(4), 12-18.

Demirer, V. \& Baki, Y. (2018). Turkce ogretmeni adaylarinin dijital oykuleme surecine iliskin gorusleri ve algilari. Kuramsal Egitimbilim Dergisi, 11(4), 718-747. https://doi.org/10.30831/akukeg.392654

Demirer, V. (2013). Ilkogretimde e-oykuleme kullanimi ve etkileri. [Unpublished PhD thesis], Necmettin Erbakan Universitesi, Egitim Bilimleri Enstitusu. Konya.

Diermyer, C. \& Blakesley, C. (2009). Story-Based Teaching and Learning: Practice and Technologies, 25Th Annual Conference on Distance Teaching and Learning, [Online]. (15.04.2019),http://www.academia.edu/download/33450525/Diermyer2009-StoryBased_Teaching_and_Learning_Practices_and_Technologies.pdf

Dush, L. (2009). Digital storytelling at an educational nonprofit: A case study and genreinformed implementation analysis. [Unpublished Ph.D. thesis]. The University of Massachusetts. [Online]. (23.05.2019) https://pdfs.semanticscholar.org/6956/d9oed1b6boe0489f7c9a34ac5f5aba1eb5cb.pdf? ga $=2.175370018 .1461538582 .1580820463-848321814.1580820463$

Duveskog, M., Tedre, M., Sedano, C. I. \& Sutinen, E. (2012). Life Planning by digital storytelling in a primary school in rural Tanzania. Journal of Educational Technology \& Society, 15(4).

Eker, C. \& Sicak, A. (2019). Sinif Ogretmeni adaylarinin birlestirilmis sinifliOgretime iliskin zihin imgeleri (Metaforlari). Mehmet Akif Ersoy Universitesi Egitim Fakultesi Dergisi, 1(37), 133153. https://doi.org/10.21764/efd.74105

Garrety, C. (2008). Digital storytelling: An emerging tool for student and teacher learning. Ames. [Unpublished Ph.D. thesis], IA: Iowa State University. [Online]. (23.05.2019) https://pdfs.semanticscholar.org/9d6b/229ac47bf68c95802d9d3e3ab5982704e2cd.pdf? ga $=2.19073080 .1461538582 .1580820463-848321814.1580820463$

Gere, J., Kozolvich, B. \& Kelin I. D. (2002). By word of mouth: A storytelling guide for the classroom. Honolulu, HI: Pacific Resources for Education and Learning.

Gezgin, D. M., Hamutoglu, N. B., Sezen Gultekin, G. \& Yildirim, S. (2019). Preservice teachers' metaphorical perceptions on smartphone, No Mobile Phone Phobia (Nomophobia) and Fear of Missing Out (FoMO). Bartin Universitesi Egitim Fakultesi Dergisi, 8(2), 733-783. DOI: 10.14686/buefad. 516540

Gomleksiz, M. N. \& Pullu, E. K. (2017). Toondoo ile dijital hikayeler olusturmanin Ogrenci basarisina ve tutumlarina etkisi. Electronic Turkish Studies, 12(32). http://dx.doi.org/10.7827/TurkishStudies.12717

Gunduz, N. (2019). Dijital Oyku yazarliginin cesitli degiskenlere gOre incelenmesi. [Unpublished master's thesis], Dokuz Eylul Universitesi, Egitim Bilimleri Enstitusu, İzmir.

Gurol, M., \& Donmus, V. (2010). Metaphors created by prospective teachers related to the concept of "Social Network". Procedia-Social and Behavioral Sciences, 9, 1489-1496.

Hathorn, P. P. (2005). Using digital storytelling as a literacy tool for the inner city middle school youth. The Charter Schools Resource Journal, 1(1), 32-38. 
Inceelli, A. (2005). Dijital hikaye anlatiminin bilesenleri. TOJET: The Turkish Online Journal of Educational Technology, 4(3).

Kabaran, G. G., Karalar, H., Altan, B. A. \& Altintas, S. (2019). Sinif Ogretmeni ve sinif Ogretmeni adaylari dijital Oyku atOlyesinde. Cumhuriyet Uluslararasi Egitim Dergisi, 8(1), 235-257. http://dx.doi.org/10.30703/cije.469461

Karakoyun, F. (2014). Cevrimici ortamda olusturulan dijital Oykuleme etkinliklerine iliskin Ogretmen adaylari ve ilkOgretim Oğrencïlerïnïn gOruslerinin incelenmesï. [Unpublished PhD Thesis]. Anadolu Universitesi, Eskisehir.

Kilic, F. (2014). Awareness and cognitive load levels of teacher candidates towards student products made by digital storytelling. Turkish Online Journal of Distance Education-TOJDE, 15 (3), 9. DOI: 10.17718/tojde.90227

Kocaman Karaoglu, A. (2015). Ogretim surecinde hikaye anlatmanin teknolojiyle degisen dogasi: dijital hikaye anlatimi.EgitimTeknolojisiKuramveUygulama, 5(2), 89-106. https://doi.org/10.17943/etku.29277

Kungeru, A. (2016). Bir ifade araci olarak dijital Oyku anlatimi. Abant Kulturel Arastirmalar Dergisi, 1(2), 33-45.

Kurudayioglu, M. \& Bal, M. (2014). Ana dili egitiminde dijital hikaye anlatimlarinin kullanimi. Sakarya Universitesi Egitim Fakultesi Dergisi, 28, 77-99.

Kutlucan, E., Cakir, R. \& Unal, Y. (2019). An action research for the training of value provided with digital storytelling. Kastamonu Education Journal, 27(5), 2187.

LaFrance, J. \& Blizzard. J. (2013). "Student Perceptions of Digital Storytelling as a LearningTool for Educational Leaders." International Journal of Educational Leadership Preparation, 8 (2). [Online]. (23.05.2019) https://digitalcommons.georgiasouthern.edu/leadership-facpubs/11

Lambert, J. (2013). Digital storytelling: Capturing lives, creating community. Routledge.

Lowenthal, P. R. \& Dunlap, J. C. (2010). From pixel on a screen to a real person in your student's lives: Establishing social presence using digital storytelling. Internet and Higher Education 13, 70-72. DOI: 10.1016/j.iheduc.2009.10.004

Menezes, H. (2012). Using digital storytelling to improve literacy skills. International Association for Development of the Information Society.

Miles, M. B.\&Huberman, M. (1994). Qualitative data analysis: A sourcebook of new methods. $2 \mathrm{~d}$ Edition. Beverly Hills, CA: Sage Publications.

Miller, S. \& Pennycuff, L. (2008). The power of story: Using storytelling to improve literacy learning. Journal of Cross-Disciplinary Perspectives in Education, 1(1), 36-43.

Niemi, H. \& Multisilta, J. (2016). Digital storytelling promoting twenty-first-century skills and student engagement. Technology, Pedagogy, and Education, 25(4), 451468.https://doi.org/10.1080/1475939X.2015.1074610

Nilsson, M. E. (2008). Digital storytelling as a tool in education. In Handbook of research on digital information technologies: Innovations, methods, and ethical issues (pp. 131-145). IGI Global.

Ohler, J. (2008). Digital storytelling in the classroom: New media pathways to literacy, learning, and creativity. Thousand Oaks, CA: Corwin Press

Patton, M. Q. (2001). Qualitative research and evaluation methods. CA: Sage.

Polater, C. (2019). Ikokul dorduncu sinifta dijital oyku yontemiyle degerler egitimi. [Unpublished master's thesis], Inonu Universitesi Egitim Bilimleri Enstitusu, Malatya.

Robin, B. (2006). The educational uses of digital storytelling. In Society for Information Technology \& Teacher Education International Conference (pp. 709-716). Association for the Advancement of Computing in Education (AACE). 
Robin, B. (2016). The power of digital storytelling to support teaching and learning. Digital Education Review, (30), 17-29. https://doi.org/10.1344/der.2016.30.17-29

Robin, B. R. (2008). Digital storytelling: A powerful technology tool for the 21st-century classroom. Theory into Practice, 47, 220-228. DOI: 10.1080/00405840802153916

Robin, B. R., \& McNeil, S. G. (2019). Digital storytelling. The International Encyclopedia of Media Literacy, 1-8. https://doi.org/10.1002/9781118978238.iemlo056

Saban, A. (2008). Okula iliskin metaforlar. Kuram ve Uygulamada Egitim Yonetimi, 55(55), 459496.

Sarica, H. C. \& Usluel, Y. K. (2016). The effect of digital storytelling on visual memory and writing skills. Computers \& Education, 94, 298309.https://doi.org/10.1016/j.compedu.2015.11.016

Sola Ozguc, C., Uzunkol, E. \& Uysal, A. Z. (2019). Sinif Ogretmeni adaylarinin rehberlik ve arastirma merkezlerine iliskin metaforik algilari. Kocaeli Universitesi Egitim Dergisi, 2(1), 48-63. http://dx.doi.org/10.33400/kuje.554572

Tabak, G. (2017). Turkcenin yabanci dil olarak Ogretiminde dijital Oyku kullanimi. [Unpublished $\mathrm{PhD}$ thesis], Erciyes Universitesi Egitim Bilimleri Enstitusu, Kayseri.

Tatli, Z. \& Aksoy, D. A. (2017). Yabanci dil konusma egitiminde dijital oyku kullanimi. Marmara Universitesi Ataturk Egitim Fakultesi Egitim Bilimleri Dergisi, 45(45), 137-152. DOI: 10.15285/maruaebd.271060

Tatli, Z. \& Bayramoglu, A. (2015). Ogretmenlik uygulamasi surecinin dijital oykuler ile yansitilmasi. Ogretim Teknolojileri ve Ogretmen Egitimi Dergisi, 4(2).

Toksun, S. E. (2019). Turkish teachers' opinions about the use of drama method. International Journal of Progressive Education, 15(3), 144-155. https://doi.org/10.29329/ijpe.2019.193.10

Tompkins, G. E. (2004). Teaching writing. Balancing process and product. Upper Saddle River: Merrill Prentice Hall.

Torres, A., Ponce, E. \& Pastor, D. (2012). Digital storytelling as a pedagogical tool within a didactic sequence in foreign language teaching. Digital Education Review, 22, 1-18. https://doi.org/10.1344/der.2012.22.1-18

Tsou, W., Wang, W. \& Tzeng, Y. (2006). Applying a multimedia storytelling website in foreign language learning. Computers \& Education, 47(1), 17-28. https://doi.org/10.1016/j.compedu.2004.08.013

Tunc, O. A \& Karadag, E. (2013). Postmodernden olusturmaciliga dijital oykuleme. Egitim ve Ogretim Arastirmalari Dergisi, 2(4), 310- 315.

Uslupehlivan, E. \& Kurtoglu Erden, M. (2018). Degerler Egitiminde Dijital Oykulerin Kullanimi. I. Uluslararasi Sosyal Bilimler Kongresi.

Uslupehlivan, E., Kurtoglu Erden, M. \& Cebesoy, U. B. (2017). Ogretmen adaylarinin dijital Oyku olusturma deneyimleri. Usak Universitesi Sosyal Bilimler Dergisi, 10(ERTE Ozel Sayisi), 122.https://doi.org/10.12780/usaksosbil.373851

Wang, S. \& Zhan, H. (2010). Enhancing teaching and learning with digital storytelling. International Journal of Information and Communication Technology Education (IJICTE), 6(2), 76-87. DOI:10.4018/jicte.2010040107

Woodhouse, J. (2008). Story-telling: A telling approach in healthcare education. [Online]. (13.01.2020) https://chesterrep.openrepository.com/handle/10034/35216

Yapicioglu, A.E. \& Korkmaz, N. (2019). Ogretmen adaylarinin fen ve matematige yOnelik algilarinin belirlenmesi: Metafor calismasi. Akdeniz Egitim Arastirmalari Dergisi, 13(29), 400-420. https://doi.org/10.29329/mjer.2019.210.21

Yildirim, A. \& Simsek, H. (2011). Sosyal bilimlerde nitel arastirma yOntemleri. Ankara: Seckin Yayincilik. 
Yilmaz, Y., Ustundag, M. T. \& Gunes, E. (2017). Ogretim materyali olarak dijital hikaye gelistirme asamalarinin ve araclarinin incelenmesi. Abant Izzet Baysal Universitesi Egitim Fakultesi Dergisi, 17 (3), 1621-1640. https://doi.org/10.17240/aibuefd.2017.17.31178-338851

Yilmaz, Y., Ustundag, M. T., Gunes, E. \& Caliskan, G. (2017). Dijital hikayeleme yontemi ile etkili Turkce ogretimi. Egitim Teknolojisi Kuram ve Uygulama, 7(2), 254-275. https://doi.org/10.17943/etku.322366

Yuruk, S. (2015). Dijital Oykulemeye dayali degerler egitiminin Ogrencilerin deger kazanimi ve tutumlarina etkisi. [Unpublished master's thesis], Firat Universitesi Egitim Bilimleri Enstitusu, Elazig.

Yuruk, S. E. \& Atici, B. (2017). Dijital Oyku temelli degerler egitimi materyallerinin Ogrencilerin deger kazanimina etkisi. Trakya Universitesi Egitim Fakultesi Dergisi, 7(1), 56-74. ISSN: 2146-071X

Yuzer, T. V. \& Kilinc, H. (2015). Acik Ogrenme sistemlerinde dijital Oykulemeden faydalanmak. Egitim ve Ogretim Arastirmalari Dergisi, 4 (1), 243-250. ISSN: 2146-9199.

\section{Biographical notes:}

Dr. Vildan DONMUS KAYA has her bachelor's degree in Department of Computer and Instructional Technologies at Firat University in 2008, master's degree in Department of Computer and Instructional Technologies at Firat University in 2012, and Ph.D. degree in Department of Curriculum and Instruction at the institute of Education Sciences at Firat University in 2018. Since 2009, she has been serving a research assistant at Firat University. She has studies on technology integration in education, online learning environment, curriculum and instruction, teacher education, and measurement and evaluation in education. She published over 30 papers and conference articles in international journals on education.

Dr. Mehmet EROGLU has his bachelor's degree in Department of Sciences at Inonu University in 2007, master's degree in Department of Education Sciences at Firat University 2012, and Ph.D. degree in Department of Curriculum and Instruction at the institute of Education Sciences at Inonu University in 2019. Since 2009, he has been serving served as a research assistant at Firat University. He has studies on curriculum and instruction, teacher education, professional development, and measurement and evaluation in education. He published over 30 papers and conference articles in international journals on education. 